\title{
Trophic interactions under stress: hypoxia enhances foraging in an estuarine food web
}

\author{
William Christopher Long ${ }^{1,2, *}$, Rochelle D. Seitz ${ }^{1}$ \\ ${ }^{1}$ School of Marine Science, Virginia Institute of Marine Science, The College of William and Mary, PO Box 1346, \\ Gloucester Pt., Virginia 23062, USA \\ ${ }^{2}$ Present address: Smithsonian Environmental Research Station, 647 Contees Wharf Rd., Edgewater, Maryland 21037, USA
}

\begin{abstract}
Ecosystem-level effects of stressors are critical to understanding community regulation, and environmental stress models are useful in describing such effects. Hypoxia is an important stressor in aquatic ecosystems that usually decreases abundance and biomass of benthic fauna. In field surveys, predator abundance is low in hypoxic areas, and in lab experiments, predators reduce their feeding rates under hypoxic conditions, leading to the hypothesis that consumer stress models (CSMs), rather than prey stress models (PSMs), apply to the systems. We tested predictions from these models with manipulative field experiments wherein we varied predator access to marked Macoma balthica clams at deep and shallow sites in the York River, Chesapeake Bay, before (June) and during (August) hypoxic episodes. In June, dissolved oxygen in deep and shallow sites was normoxic $\left(>2 \mathrm{mg} \mathrm{l}^{-1}\right)$ for most of the experiment. In August, the shallow zone remained normoxic, while the deep zone experienced several hypoxic episodes. During hypoxia, predation rates in hypoxic sites were more than twice those in normoxic sites, whereas mortality due to physical stress did not differ between time periods or depths. Ambient clam densities were lower at the deep sites than at the shallow sites, and in August than in June. We conclude that hypoxia increased the susceptibility of benthic prey to predation, enhancing infaunal secondary production available to predators, but concurrently reducing the resilience of the benthic community. These findings are inconsistent with the predictions of CSMs, indicating that PSMs better describe this system.
\end{abstract}

KEY WORDS: Environmental stress models · Food web - Hypoxia · Predation - Predator-prey · Macoma balthica

Resale or republication not permitted without written consent of the publisher

\section{INTRODUCTION}

\section{Predation and hypoxia}

Environmental stress is a major determinant of community structure (e.g. Menge \& Sutherland 1987). Species respond differently to the same stressor, such that an increase in the magnitude of a stressor is expected to shift the outcome of interactions between species to favor the one with greater tolerance. This expectation has been expressed in consumer stress models (CSMs), conceptual models which predict that a stressor will reduce predation when consumers are less tolerant of a stressor than their prey (Menge \& Sutherland 1987).
Alternatively, prey stress models (PSMs) predict that a stressor will increase predation when consumers are more tolerant of, or resilient to, the stressor than their prey (Menge \& Olson 1990).

Anthropogenic eutrophication of estuaries has had widespread effects on these ecosystems (Kemp et al. 2005), including development of hypoxic, or oxygendepleted, bottom waters (Diaz \& Rosenberg 1995). Hypoxia (here defined as dissolved oxygen [DO] concentrations $<2 \mathrm{mg} \mathrm{l}^{-1}$ ) is an important stressor of benthic communities, and its effects are well documented in many systems (e.g. Diaz et al. 1992, Powers et al. 2005). Typically, abundance, biomass, recruitment, and diversity decrease, and there is a shift from large, 
long-lived species to small, opportunistic species. The magnitude of these effects generally increases with the severity of hypoxic stress.

Hypoxia has a multitude of non-lethal effects. Metabolism, and thus oxygen demand, decreases (Wu 2002), reducing growth and reproductive output (e.g. Grove \& Breitburg 2005, Long 2007). Infaunal organisms migrate vertically in the sediment, stretching their siphons or palps above the benthic boundary layer into higher DO concentrations, and they may expose themselves on the surface or float in the water column (Brafield 1963, Rosenberg et al. 1991, Taylor \& Eggleston 2000, Seitz et al. 2003). Almost all species decrease oxygen demand by decreasing activity and feeding rates (Sagasti et al. 2001).

These effects, especially the behavioral responses, potentially increase the availability of benthic fauna to their predators. The closer proximity of infaunal prey to the sediment surface and extension of siphons and palps decrease predator searching time. However, the responses of predators to hypoxia may jeopardize their ability to take advantage of stressed prey. Many predators in these systems are highly mobile, and have a much lower tolerance for hypoxia than do sessile prey (Das \& Stickle 1993, Seitz et al. 2003). Field studies on predator abundance show a migration of motile predators out of hypoxic areas, often followed by a reinvasion shortly after hypoxia abates (Pihl et al. 1991, Das \& Stickle 1994, Bell \& Eggleston 2005, Powers et al. 2005). Almost universally, laboratory experiments show a decrease in predation rate under hypoxic conditions (Breitburg et al. 1994, Breitburg et al. 1997, Sagasti et al. 2001, Seitz et al. 2003), mostly due to a decrease in predator activity.

Either CSMs or PSMs could apply to hypoxic systems. Some authors (Sagasti et al. 2001, Powers et al. 2005) argue that, because the predators have lower tolerances for hypoxia than their prey and avoid hypoxic zones, hypoxia is likely to act as a refuge for prey species, as predicted by CSMs. Others suggest that PSMs are more appropriate and that predators consume prey stressed by hypoxia, either during a hypoxic episode (Rahel \& Nutzman 1994) or immediately afterwards, before the prey have time to recover (Nestlerode \& Diaz 1998). Foraging can occur during hypoxia; fish in a freshwater lake foraged in hypoxic waters (Rahel \& Nutzman 1994), and predation on tethered polychaetes in the York River, Chesapeake Bay (USA), occurred at low levels during hypoxia (Nestlerode \& Diaz 1998). Gut contents of predators in the York River shifted to include larger and deeper-burrowing prey items after hypoxic events (Pihl et al. 1992). These studies suggest that PSMs are appropriate, but the studies did not quantify the rate of predation, so they could not distinguish between PSMs and CSMs. To date, the only field study to definitively support CSMs was a caging study in Narragansett Bay, Rhode Island (USA) showing that mussels suffered no predation during hypoxia (Altieri \& Witman 2006).

\section{Study organisms}

The thin-shelled clam Macoma balthica was the experimental prey species. $M$. balthica is a deposit and facultative suspension feeder that is the biomass-dominant macrofaunal species in mud habitats of Chesapeake Bay, comprising over $85 \%$ of the biomass in some habitats (Holland et al. 1977). Its shell length is typically $<40 \mathrm{~mm}$, and it contributes greatly to energy flow and benthicpelagic coupling (Baird \& Ulanowicz 1989). M. balthica is tolerant of hypoxia, with an LT (lethal time) $50 \%$ of 15 d under near-anoxic conditions (Henriksson 1969). In response to hypoxia, $M$. balthica extends its siphons into the water column to reach normoxic waters within $24 \mathrm{~h}$ (Seitz et al. 2003) and migrates upward in the sediment within 72 h (Brafield 1963, Long et al. 2008). As M. balthica avoids predation by burying down to $40 \mathrm{~cm}$ in the sediment (Hines \& Comtois 1985), a decrease in burial depth with hypoxia is likely to make this species more vulnerable to predation (Clark et al. 1999a,b, De Goeij et al. 2001, Seitz et al. 2001).

Predators of Macoma balthica in the York River include the blue crab Callinectes sapidus (Seitz et al. 2001). The blue crab is a key link in the food web (Fig. 1) (Baird \& Ulanowicz 1989), with up to $55 \%$ of its diet consisting of clams (Hines et al. 1990). Three benthic piscine predators, the Atlantic croaker Micropogonias undulatus, spot Leiostomus xanthurus and hogchoker Trinectes maculatus, nip M. balthica siphons

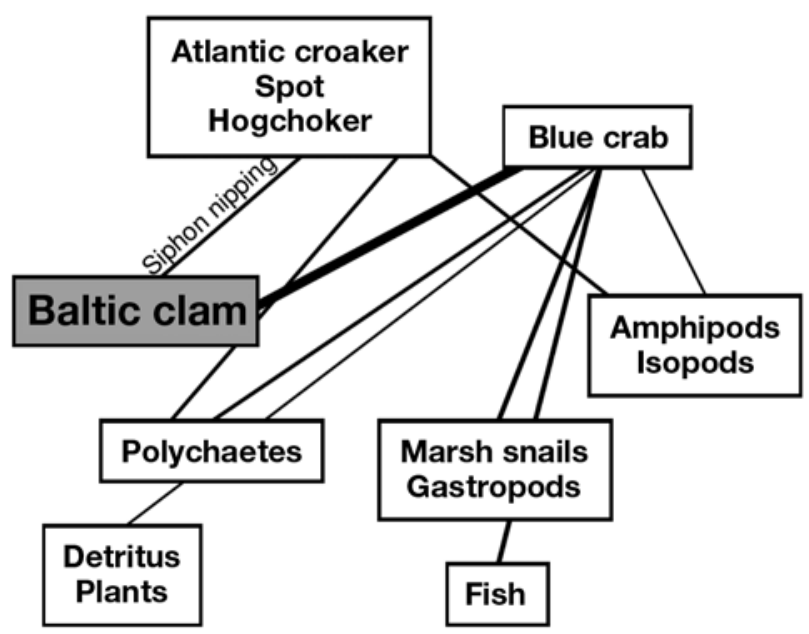

Fig. 1. Macoma balthica. Simplified food web showing important linkages for the Baltic clam in the Chesapeake Bay. Adapted from Lipcius et al. (2007) 
(Fig. 1) (Hines et al. 1990, Pihl et al. 1992, Powers et al. 2005). Siphon nipping can force $M$. balthica to migrate vertically, making it more susceptible to other predators (e.g. birds; De Goeij et al. 2001). These predators, however, have low tolerances for hypoxia (Das \& Stickle 1993) and generally avoid hypoxic areas (Pihl et al. 1991, Bell \& Eggleston 2005). In the present study, we quantify the effects of hypoxia on the rate of predation in a soft-sediment community using a manipulative caging experiment to test the hypotheses that hypoxia increases (supporting PSMs) or decreases predation (supporting CSMs) in the York River system.

\section{MATERIALS AND METHODS}

We conducted this study in the York River, a tributary of Chesapeake Bay (Fig. 2), which is one of the largest eutrophic estuaries in the world and which suffers from seasonal hypoxia (Officer et al. 1984, Kemp et al. 2005). Hypoxia in the York River is episodic and primarily tidally driven; it tends to develop during neap tides, lasts about a week, and then dissipates when the spring tides mix oxygen-rich waters down from the surface (Haas 1977, Kuo \& Neilson 1987).

At our field sites, hypoxic waters regularly develop in deeper areas during the summer (Pihl et al. 1991). In 2005, we haphazardly chose 4 replicate sites in both shallow (3 to $4 \mathrm{~m}$ ), and deep (10 to $12 \mathrm{~m}$ ) water (Fig. 2); environmental factors such as sediment type (all sites were mud or sandy mud), temperature, and salinity were similar among all sites. At each site, SCUBA divers established three $50 \times 50 \mathrm{~cm}$ plots marked with a PVC frame: (1) caged, (2) uncaged, and (3) partially caged. We transplanted 40 Macoma balthica (shell lengths 10 to $35 \mathrm{~mm})$, collected from the York River and marked with red permanent ink, into each plot. This resulted in a density of $160 \mathrm{~m}^{-2}$, which is within the natural range (Seitz et al. 2005). We placed a full cage made from galvanized steel hardware cloth $(1 \mathrm{~cm}$ mesh) over each plot for a minimum of $24 \mathrm{~h}$ to allow the clams to acclimate and bury (Seitz et al. 2001). After acclimation, we removed the cage on the uncaged plot, and replaced the cage on the partially caged plot with a partial cage. The partial cage had a $25 \times$
$25 \mathrm{~cm}$ hole in the center of the top and a $25 \times 7 \mathrm{~cm}$ hole in each of the sides. The partial cages allowed predator access but may have excluded larger piscine predators. The cages were $14 \mathrm{~cm}$ high and were inserted $7 \mathrm{~cm}$ into the sediment so the side holes were flush with the sediment surface.

We left the plots undisturbed for approximately $28 \mathrm{~d}$ before they were re-sampled with a suction apparatus to a depth of $40 \mathrm{~cm}$ (Eggleston et al. 1992). We counted and measured marked Macoma balthica, and calculated percent recovery for each plot. We identified unmarked ambient bivalves in each of the plots to species. The experiment was performed once in June, under normoxic conditions, and once in the period from August to September, under episodic hypoxic conditions. Two sites, one shallow and one deep, were unexpectedly destroyed during the experiment.

We used a continuous water-quality recorder (DataSonde 3, Hydrolab) to record bottom DO, tem-

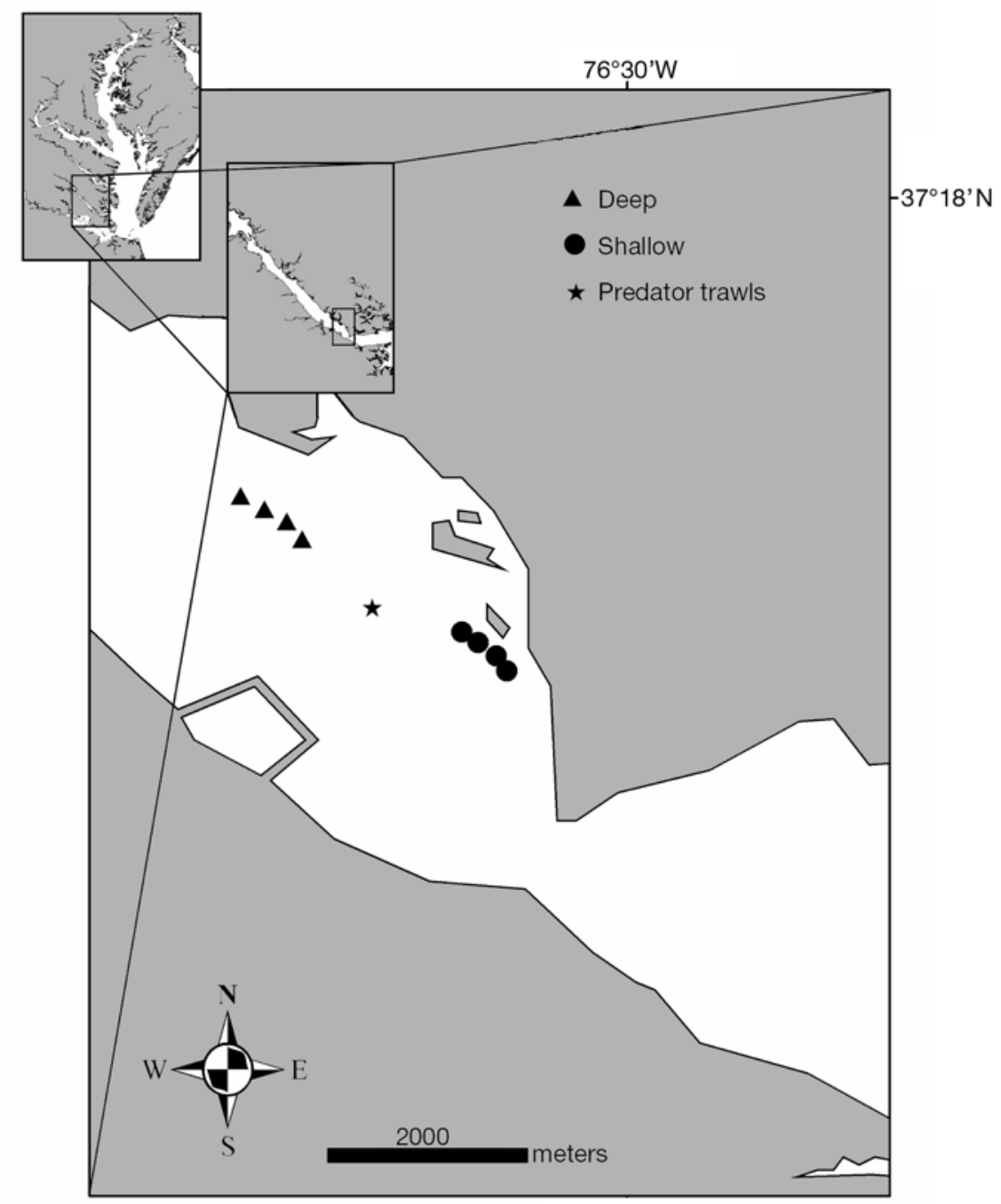

Fig. 2. Chesapeake Bay (left inset), the York River (middle inset), and our study sites at Gloucester Point (large frame) 
perature, and salinity every $5 \mathrm{~min}$. The recorder was placed at the most downriver deep site (Fig. 2) and was downloaded and serviced weekly. We used it for all but the first week of the June experiment and during $1 \mathrm{wk}$ of the August experiment, after which it was permanently damaged. Once, during the course of the experiments, we applied a linear correction factor to the raw DO data when there was significant drift in the readings after deployment. DO measurements were smoothed by applying a running 5-point average (Fig. 3). Spot measurements (Fig. 3) were made every 3 to $4 \mathrm{~d}$ at each of the sites using a DO probe (YSI Model 85, Yellow Springs Instruments).
We calculated predation based on the recovery of marked Macoma balthica. Recovery in the caged plots averaged $87 \%$ in June and $85 \%$ in August. Marked undamaged shells of $M$. balthica were counted as recovered for the purpose of calculating predation, because they represented non-predatory mortality. The predation rate was calculated using:

$$
S=N \mathrm{e}^{-p t}
$$

where $S$ is the number of recovered clams, $N$ is the initial number, $p$ is the instantaneous predation rate per day, and $t$ is the time elapsed. The rate of predation, $p$, was calculated for both the uncaged and partially caged plots in each site. The recovery of clams in the

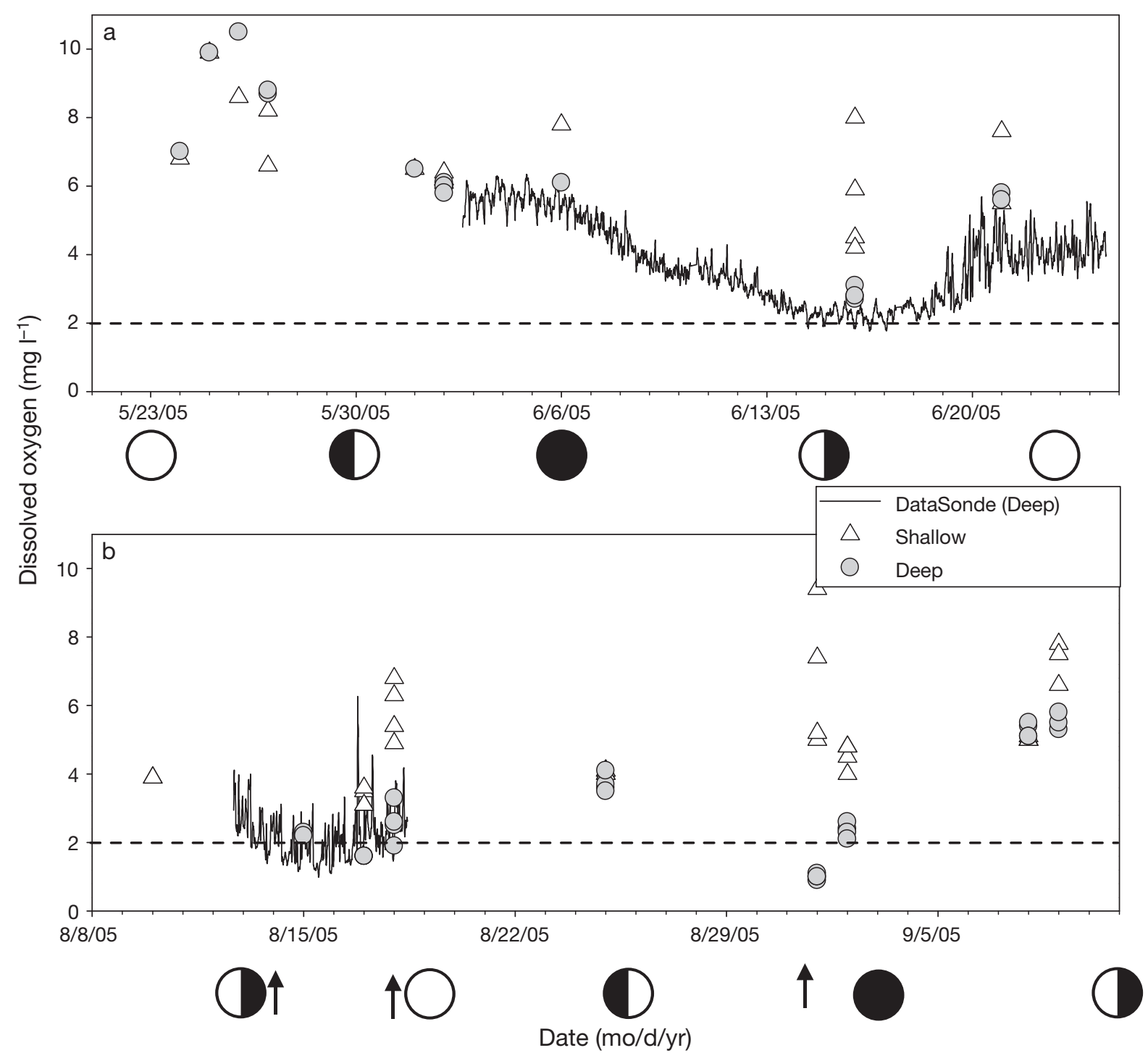

Fig. 3. Dissolved oxygen concentrations observed at study sites in the York River during the (a) June and (b) August experiments. Readings under dashed line at $2 \mathrm{mg} \mathrm{l}^{-1}$ are considered nominally hypoxic. Lines represent continuously recorded DataSonde measurements taken at deep site 1 . YSI Model 85 measurements at: deep $(\bigcirc)$; and shallow sites $(\Delta)$. $(0,0)$ : lunar phase; $(\uparrow)$ : hypoxia 
caged plot was used as the initial number, $N$, thus accounting for sampling error (i.e. non-recovered clams). The rate of non-predatory mortality was calculated with the same equation using the recovery of dead, marked, whole $M$. balthica shells in the partially caged plot as $1-S$ and the recovery in the caged plots as $N$. In sites where the caged plots could not be used, the mean recovery from caged plots within that depth and time period was used as Ninstead. This happened only twice, once because a failure of the suction sampler resulted in a lost sample, and once because a blue crab had been inadvertently included in the cage, as indicated by a high abundance of marked shell fragments due to predation and a low recovery of live $M$. balthica $(13 \%)$.

Predation and ambient bivalve densities were analyzed with an ANOVA with Time period (pre- or postonset of hypoxia), Depth (deep or shallow), and Plot (uncaged or partially caged) as factors and Site (nested within Depth and Time) as a blocking factor. Nonpredatory mortality was analyzed with a 2-way ANOVA with Time and Depth as factors. Where a significant interaction effect was observed, a StudentNewman-Keuls (SNK) post-hoc multiple comparison test was performed. The assumption of homogeneity of variance was verified using Levine's test for all ANOVA-type analyses. In all cases, this assumption was met.

Predators were sampled by the Virginia Institute of Marine Science (VIMS) Juvenile Finfish and Blue Crab Trawl Survey, which takes monthly trawls at sites in the Virginia portion of the Chesapeake Bay and its tributaries. The survey uses a $9 \mathrm{~m}$ semi-balloon otter trawl (38.1 mm stretch-mesh body, $6.35 \mathrm{~mm}$ mesh codend liner). Each month, one 5 min trawl was performed at the sampling site (Fig. 2). All animals were identified to species, counted, and measured.

\section{RESULTS}

In June, before hypoxia, DO in deep and shallow sites was normoxic $\left(>2 \mathrm{mg} \mathrm{l}^{-1}\right)$ for most of the experimental period (Fig. 3a). DO did not differ between deep and shallow sites (1-way ANOVA: $F_{1,32}=0.87$; $\mathrm{p}=0.357 ; \mathrm{N}=34 ;$ Deep $=6.1 \pm 0.58[\mathrm{SE}] \mathrm{mg} \mathrm{l}^{-1}$; Shallow $=6.8 \pm 0.35 \mathrm{mg} \mathrm{l}^{-1}$ ). During August, the shallow zone remained normoxic, but the deep zone experienced several hypoxic episodes (Fig. 3b). DO in the deep sites was significantly lower than in the shallow sites $\left(F_{1,56}=25.98 ; \mathrm{p}<0.0005 ; \mathrm{N}=58 ;\right.$ Deep $=3.0 \pm$ $0.30 \mathrm{mg} \mathrm{l}^{-1}$, Shallow $=5.1 \pm 0.28 \mathrm{mg} \mathrm{l}^{-1}$ ). During both time periods, the deep sites were about $1^{\circ} \mathrm{C}$ cooler than the shallow sites and 1 psu more saline, as expected due to the stratification of the system.
Recovery rates of marked Macoma balthica were generally lowest in open plots, intermediate in partial cages, and highest in full cages. Predation rates differed significantly by the interaction between Time period (pre- or post-onset of hypoxia) and Depth (Table 1). Predation was significantly higher at the deep sites after hypoxia than in the shallow sites after hypoxia (Fig. 4a) (SNK: p < 0.05) or in the deep sites before hypoxia $(p<0.01)$. There was a non-significant trend $(p<0.1)$ for higher predation at the shallow sites after hypoxia as compared to before. A significant interaction existed between Plot (uncaged and partially caged) and Time (Table 1), with uncaged plots having significantly higher predation rates than partially caged plots in August (Fig. 4b) ( $\mathrm{p}<0.01)$, but not in June. No major fouling occurred on the cages over the course of the experiment.

Ambient clams were significantly less dense in the deep sites than in the shallow sites (Fig. 4c) (ANOVA: $\left.F_{1,21}=25.90, \mathrm{p}<0.0005, \mathrm{~N}=44\right)$, and less dense in August than in June $\left(F_{1,21}=13.23, \mathrm{p}=0.002\right)$. Nonpredatory mortality was $0.055 \pm 0.014[\mathrm{SE}] \mathrm{d}^{-1}$ and did not differ by Depth (2-way ANOVA: $F_{1,10}=0.00, \mathrm{p}=$ $0.974, \mathrm{~N}=14)$, Time $\left(F_{1,10}=1.04, \mathrm{p}=0.332\right)$, or interaction $\left(F_{1,10}=2.08, \mathrm{p}=0.180\right)$.

Predator density and composition changed between the June and August experiments (Fig. 5). In May and early June, predator density was low and dominated by blue crab Callinectes sapidus, Atlantic croaker Micropogonias undulatus, and hogchoker Trinectes maculatus. In August and September, the predator assemblage was dominated by spot Leiostomus xanthurus and T. maculatus, which resulted in a near doubling of the predator abundance from early June to early August. C. sapidus were also abundant in September. There were no clear trends in the size of piscine predators; the mean length of $M$. undulatus was $238 \mathrm{~mm}$ and the monthly means varied from $205 \mathrm{~mm}$ in September to $278 \mathrm{~mm}$ in June. Mean length

Table 1. Fully crossed 3-way ANOVA table for predation rates with Depth (deep and shallow), Time (pre- or post-onset of hypoxia), and Cage (partial and uncaged) as main factors, and Site (nested within Depth and Time) as a blocking factor

\begin{tabular}{|lrcrc|}
\hline Source of variation & df & SS & \multicolumn{1}{c|}{$F$} & $\mathrm{p}$ \\
\hline Depth & 1 & 0.00171 & 2.86 & 0.122 \\
Time & 1 & 0.01514 & 25.22 & 0.001 \\
Cage & 1 & 0.01239 & 20.65 & 0.001 \\
Depth $\times$ Time & 1 & 0.00303 & 5.06 & 0.048 \\
Depth $\times$ Cage & 1 & 0.00102 & 1.69 & 0.222 \\
Time $\times$ Cage & 1 & 0.00778 & 12.97 & 0.005 \\
Depth $\times$ Time $\times$ Cage & 1 & 0.00081 & 1.36 & 0.271 \\
Site $($ Depth Time) & 10 & 0.00686 & 1.14 & 0.419 \\
Error & 10 & 0.00600 & & \\
\hline
\end{tabular}




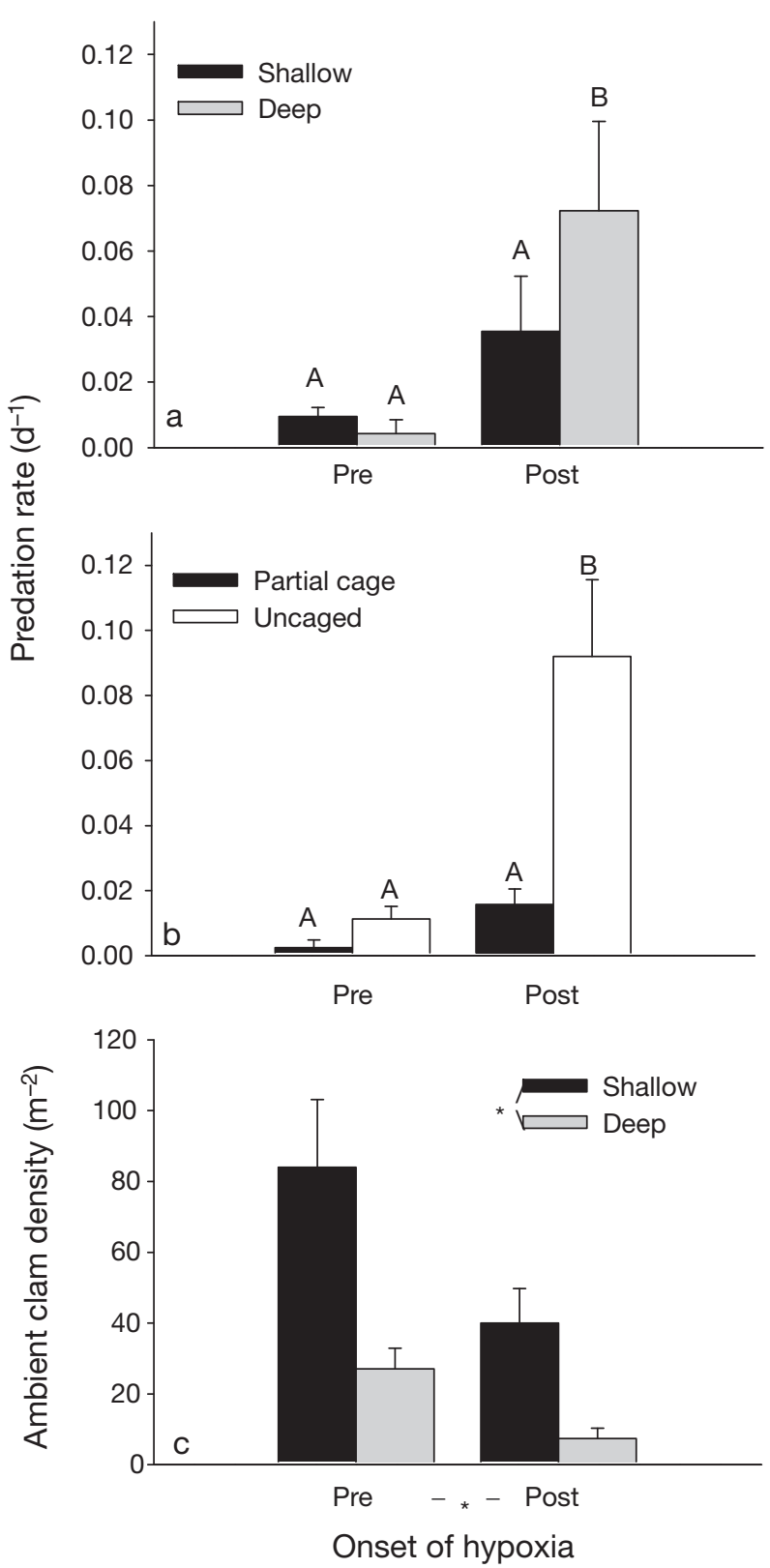

Fig. 4. (a) Predation rate $(\mathrm{N}=10)$ and (b) caging artifacts (expressed as a mortality rate; $\mathrm{N}=10$ ) at each site during each experiment. Bars with different letters above them differ at the 0.05 level (Student-Newman-Keuls). (c) Ambient bivalve densities at both depths during each experiment. Levels within a factor marked with an asterisk differ at the 0.05 level (ANOVA: $\mathrm{N}=28$ ). Error bars are $+1 \mathrm{SE}$

of T. maculatus was 109 and varied from $92 \mathrm{~mm}$ in August to $123 \mathrm{~mm}$ in May and September. L. xanthurus were only abundant in late summer and had a mean length of $116 \mathrm{~mm}$. C. sapidus increased slightly in size between May (mean carapace width $=51 \pm 11$ [SE] $\mathrm{mm})$ and September $(75 \pm 13 \mathrm{~mm})$.

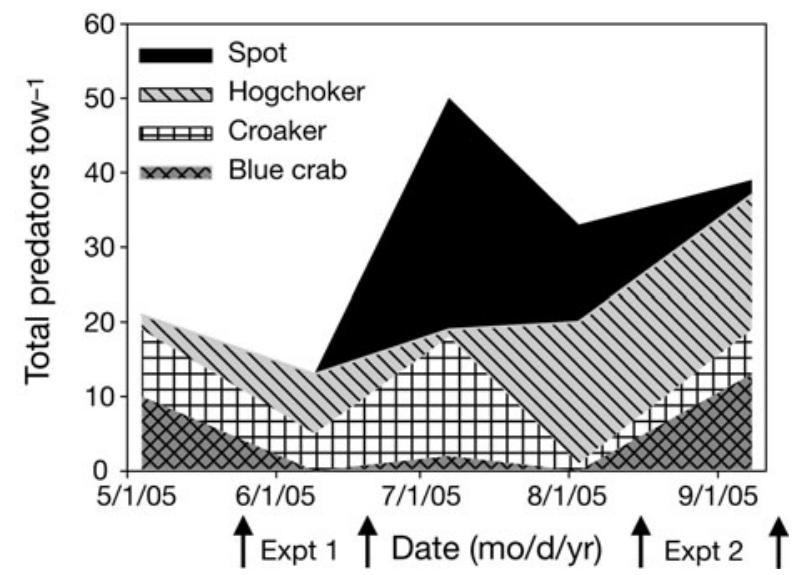

Fig. 5. Cumulative monthly predator density from the VIMS Juvenile Finfish and Blue Crab Trawl Survey. Only epibenthic predator species are shown. $(\uparrow)$ : beginning and end of Expt 1 (June, prior to hypoxia), and Expt 2 (August, during hypoxia)

\section{DISCUSSION}

Patterns of dissolved oxygen concentrations in the summer of 2005 were similar to those observed during strong hypoxic years in the York River (Pihl et al. 1991). Our time series of DO corresponded well with the tidal regime, with a twice daily cycling of about $\pm 0.5 \mathrm{mg} \mathrm{l}^{-1}$ around a daily mean, as well as a longer cycle that correlated with the neap-spring tidal cycle (Haas 1977). Although there were hypoxic excursions lasting only 1 to $2 \mathrm{~h}$ during our nominally normoxic experiment, this duration of hypoxia is not long enough to cause behavioral changes in Macoma balthica; in laboratory experiments $M$. balthica extended their siphons after about $24 \mathrm{~h}$ of exposure to hypoxia (Seitz et al. 2003), and vertically migrated after 48 to $72 \mathrm{~h}$ (Long et al. 2008). In contrast, during the August experiment, there were at least 2 hypoxic episodes at the deep sites, one around 17 August, and one around 1 September. During the first episode, DO dropped to less than $1.2 \mathrm{mg} \mathrm{l}^{-1}$ and lasted at least $4 \mathrm{~d}$, which is long enough for $M$. balthica to exhibit behavioral responses to hypoxia. During the second episode, severe hypoxia occurred, as the DO dropped below $1 \mathrm{mg} \mathrm{l}^{-1}$.

In our experiment, predation varied with time period, depth, and DO. The increase in predation in the shallow areas from June to August can be explained by the increase in predator abundance observed over this period. The higher predation rates in August in deep areas (with episodic hypoxia) compared to both the rates in deep areas in June (with normoxia) and in shallow areas in June and August (with normoxia), is counter to expectations based on laboratory and field studies where predators have much lower tolerances 
for hypoxia than Macoma balthica (Henriksson 1969, Bell \& Eggleston 2005) and feed at a lower rate under hypoxic conditions (Seitz et al. 2003). Studies with ultrasonically tagged crabs indicate that crabs in hypoxic areas do not feed after relaxation of the hypoxic events (Bell et al. 2003a,b), however, it is possible that other, unstressed crabs from outside the hypoxic area may be able to invade and feed immediately after relaxation of hypoxia.

We suggest that the pattern of higher predation in deep zones during hypoxia derives from the predators' optimal foraging behavior. In June, there is no hypoxia to stress either the predators or the prey. At that time, the prey populations are denser in the shallow zones (Fig. 6a), probably because of the annual hypoxic conditions that occur in deeper areas and cause mortality of infauna there (e.g. Powers et al. 2005). Lower densities in the deep zone would increase searching time of the predators; thus, they preferentially forage in the

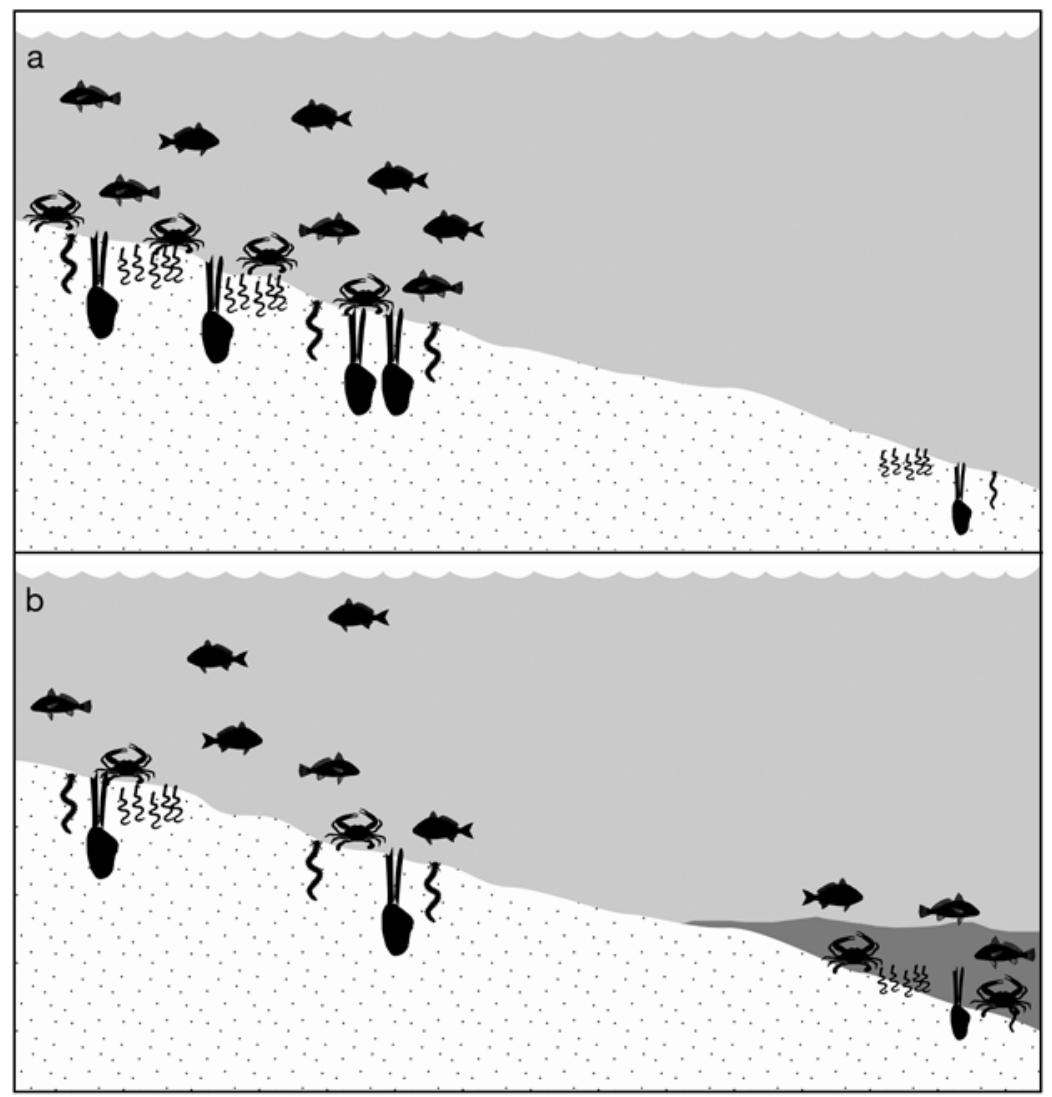

Fig. 6. Predator and prey behavior (a) before and (b) after onset of hypoxia (includes episodes of hypoxia). Stippling: sediment; light gray shading: normoxic water column; dark gray shading: extent of hypoxic water. Infaunal clams and polychaetes are pictured with relative position in relation to the sediment-water interface. (a) Before hypoxia, predators feed in shallow areas where prey are more abundant. (b) During hypoxia, prey species migrate vertically and become more vulnerable to epibenthic predators. Predators move in to feed either during a hypoxic episode or after relaxation before the prey rebury shallow areas (Clark et al. 1999a,b). For example, blue crabs forage with tactile probing and will leave an area if few prey items are detected, but will continue to search in an area if multiple prey are encountered (Clark et al. 1999a,b). Throughout the summer, predation reduces prey densities in the shallows (Holland et al. 1977). When hypoxia develops, the prey species in the deep zone become stressed and exhibit behaviors that make them easier to find and thus more vulnerable to predation (e.g. clams extending siphons and reducing burial depths; Seitz et al. 2003, Long et al. 2008). Therefore, during periods of episodic hypoxia, although prey densities in the deep areas are lower than those in shallow areas, a predator's searching time is much lower due to the increased susceptibility of prey to encounters, and predators can exploit the prey in this area at a higher rate (Fig. 6b). These results therefore support PSMs rather than CSMs, whereby prey are more stressed than predators, allowing predators to increase the rate of predation.

In our experiments, we could not distinguish whether predation occurred during hypoxia or shortly after each hypoxic episode because of the episodic nature of hypoxia in this system and the length of our experiments. Two distinct hypoxic episodes occurred during August, and the predators could have been foraging at any time during the $28 \mathrm{~d}$ experiment. Because most predators avoid hypoxic areas, foraging probably occurred soon after hypoxia but before the prey recovered (Pihl et al. 1992); however, our data do not rule out the alternative of predation during hypoxia (Rahel \& Nutzman 1994, Nestlerode \& Diaz 1998). Our results indicate that hypoxia is the driving force of the enhanced predation and prey mortality in the deep zone, regardless of when that predation takes place.

Caging artifacts differed by time period, but not by depth. Partial cages may have provided limited protection against predation, explaining the lower predatory mortality in the partially caged plot as compared to the uncaged plot. Some predators, especially large fish such as Atlantic croaker Micropogonias undulatus with lengths $>15 \mathrm{~cm}$, may not have been able to access the clams in the partial cages, feeding only in the uncaged plots. Blue crab Callinectes sapidus had access to partial 
cages, as we found molted exoskeletons in the partial cage plots, and blue crabs were at high densities during late August and early September during our hypoxic experiments. The major change in the predator assemblage between June and August was the increase in the densities, but not the sizes, of all predators, especially fish predators. The temporal patterns in predator density may thus explain the greater caging artifacts in August, when more fish predators would be feeding preferentially in uncaged plots instead of partially caged plots. Caging artifacts did not differ between deep and shallow areas, indicating that our conclusions regarding depth differences were robust.

The results of the caging artifacts indicate that future experiments in this system may have increased power by dispensing with the partial cage treatment. Partial cages either had no effect, or provided a partial refuge from predation, indicating that it is not necessary to control for caging in this system. Using a non-blocked design would also increase statistical power, though it would increase the logistical difficulties of relocating multiple plots in zero-visibility diving conditions.

Based on our finding that predation rates were higher during periods of episodic hypoxia than under normoxic conditions, a shift in our concept of hypoxia's effects on trophic dynamics and energy flow is necessary. Previously, it had been assumed that a CSM applies to this system because benthic infauna suffer mortality during hypoxia and predators avoid hypoxic areas; it has been concluded that the majority of the mortality in hypoxic areas is caused by hypoxic stress rather than by predation (Sagasti et al. 2001, Powers et al. 2005). Under this assumption, the energy from animals that die directly from hypoxic stress would enter the microbial loop, rather than being transferred to predators. Thus, hypoxia would have a net negative effect on energy transfer to higher trophic levels and fishery species (Baird et al. 2004, Altieri \& Witman 2006).

In our study, predation increased significantly during episodic hypoxia, whereas non-predatory mortality did not increase. In laboratory experiments, Macoma balthica can survive for more than $4 \mathrm{~d}$ under mild hypoxia (Henriksson 1969, Seitz et al. 2003), such as they experienced here, so we did not expect to see an increase in non-predatory mortality. As predation increased during periods with hypoxia and the majority of the biomass was passed up to higher trophic levels rather than into the microbial loop, episodic hypoxia can have a positive effect on trophic transfer to predators. This enhanced flow of secondary production likely depends on the prey species. Some species have evolved strong shells, such as Mercenaria mercenaria, or aggregative behavior, such as Mytilus edulis (Altieri \& Witman 2006), in response to predators. Such species probably do not exhibit increased vulnerability during hypoxia, because behavioral changes during hypoxic conditions should not affect their primary defense (Vermeij 1987). In contrast, species such as Macoma balthica and Mya arenaria (Taylor \& Eggleston 2000), which have evolved a deep burial depth in response to predators, are more likely to be more vulnerable to predators under hypoxia because they migrate to the sediment surface where they are easily detected.

These results also indicate that the spatial and temporal scales of hypoxic episodes determine trophic effects (Diaz \& Rosenberg 1995, Eby \& Crowder 2004), as observed in other consumer-prey interactions (Orrock et al. 2003). Our hypoxic sites were in close proximity (100s of meters) to shallow normoxic sites, where predators congregate during hypoxia (Lenihan et al. 2001, Eggleston et al. 2005). Predatory density and predation pressure can be elevated on the outside edge of hypoxic patches during hypoxic episodes (Lenihan et al. 2001). Similarly, reinvasion and predation by predators in hypoxic areas is likely to be most intense along the inside edge of hypoxic patches after hypoxia relaxes (Clark et al. 1999b, Eggleston et al. 2005). If a hypoxic patch is large ( $\gg 1000 \mathrm{~m}$ in diameter), predators may not be able to exploit vulnerable prey in central areas before the prey recover. Although our study allows inference regarding changes in predator-prey interactions during episodic hypoxia ( $<1 \mathrm{wk})$, it may also apply to systems where hypoxia lasts weeks or months. In the Rappahannock River of Chesapeake Bay, extended periods of hypoxia can be preceded by one or more short episodes of hypoxia (Llansó 1992), which would give predators a chance to prey upon much of the infaunal biomass. Furthermore, our study does not preclude active foraging by predators during hypoxia (Rahel \& Nutzman 1994, Nestlerode \& Diaz 1998). Ultimately, if hypoxia is severe enough, benthos within a hypoxic zone will be killed, either by physiological stress (Seitz et al. 2003, Powers et al. 2005, Altieri \& Witman 2006) or by predation, and the relative importance of each is probably influenced by the duration and spatial extent of hypoxia.

Hypoxia has long been recognized as a severe environmental degradation that devastates benthic communities (Diaz \& Rosenberg 1995). We demonstrate that, under certain conditions, decreases in the benthos can be primarily attributed to enhanced predation on stressed prey and not to mortality from hypoxic stress. Regardless of the proximal cause, this decrease in abundance and biomass may lead to a reduction in net annual benthic production. However, the impact on production in higher trophic levels in the short term is probably not as negative as has been thought previously, and may be positive. Indeed, there has been no observed decrease in fisheries yield in the Chesapeake 
Bay attributable to hypoxia, despite an increase in the spatial and temporal extent of hypoxia over the past few decades (Kemp et al. 2005). Moreover, the yield of some fisheries in the Gulf of Mexico increased during 4 decades of increasing hypoxia, suggesting that any effects of hypoxia on the nekton are masked by compensatory forces (Chesney \& Baltz 2001).

Though our findings demonstrate that the effects of periodic hypoxia may increase predation and thus transfer of secondary production to upper trophic levels, this does not imply that hypoxia and the associated eutrophication are insignificant. In the Neuse River, North Carolina (USA), habitat compression and the resulting increase in predator density can cause an increase in conspecific consumption in blue crabs (Eggleston et al. 2005), and this may have a greater effect on predator populations than does food limitation (Aumann et al. 2006). However, these studies do not account for increased availability of prey due to hypoxia.

The effect of a stressor on consumer-prey interactions sometimes can be predicted based on the relative tolerance of the species to that stressor (e.g. Altieri \& Witman 2006), but, as in this study, this is not always the case (e.g. Thomson et al. 2002). In the York River system, subtle changes in prey behavior under hypoxic stress (e.g. reduced burial depth) have a substantial effect on trophic dynamics, as predation increases during hypoxia.

Acknowledgements. This work was supported by a grant from the NOAA National Sea Grant, Essential Fish Habitat Program, and the Commonwealth of Virginia. W.C.L. was supported by an EPA GRO fellowship. We thank B. Brylawski for help in the field and lab and M. Seebo for help in the field and with SCUBA diving. We thank R. Diaz, R. Lipcius, D. Wolcott, B. Brylawski, J. Long and 5 anonymous reviewers, whose comments on earlier drafts substantially improved this manuscript. Symbols in Fig. 6 were courtesy of the Integration and Application Network (ian.umces.edu/symbols), University of Maryland Center for Environmental Science. Predator abundance data was graciously provided by the VIMS Juvenile Finfish and Blue Crab Survey (www.fisheries.vims.edu/trawlseine/mainpage.htm). This paper is Contribution No. 2888 of The Virginia Institute of Marine Science.

\section{LITERATURE CITED}

Altieri AH, Witman JD (2006) Local extinction of a foundation species in a hypoxic estuary: integrating individuals to ecosystem. Ecology 87:717-730

Aumann CA, Eby LA, Fagan WF (2006) How transient patches affect population dynamics: the case of hypoxia and blue crabs. Ecol Monogr 76:415-438

Baird D, Ulanowicz RE (1989) The seasonal dynamics of the Chesapeake Bay ecosystem. Ecol Monogr 59:329-361

Baird D, Christian RR, Peterson CH, Johnson GA (2004) Consequences of hypoxia on estuarine ecosystem function: energy diversion from consumers to microbes. Ecol Appl $14: 805-822$
Bell GW, Eggleston DB (2005) Species-specific avoidance responses by blue crabs and fish to chronic and episodic hypoxia. Mar Biol 146:761-770

Bell GW, Eggleston DB, Wolcott TG (2003a) Behavioral response of free-ranging blue crabs to episodic hypoxia. I. Movement. Mar Ecol Prog Ser 259:215-225

> Bell GW, Eggleston DB, Wolcott TG (2003b) Behavioral response of free-ranging blue crabs to episodic hypoxia. II. Feeding. Mar Ecol Prog Ser 259:227-235

Brafield AE (1963) The effects of oxygen deficiency on the behavior of Macoma balthica (L.). Anim Behav XI:2-3

Breitburg DL, Steinberg N, DuBeau S, Cooksey C, Houde ED (1994) Effects of low dissolved oxygen on predation on estuarine fish larvae. Mar Ecol Prog Ser 104:235-246

Breitburg DL, Loher T, Pacey CA, Gerstein A (1997) Varying effects of low dissolved oxygen on trophic interactions in an estuarine food web. Ecol Monogr 67:489-507

Chesney EJ, Baltz DM (2001) The effects of hypoxia on the Northern Gulf of Mexico coastal ecosystem: a fisheries perspective. In: Rablais NN, Turner RE (eds) Coastal hypoxia: consequences for living resources and ecosystems. Coastal and Estuarine Studies 58, American Geophysical Union, Washington, DC, p 321-354

Clark ME, Wolcott TG, Wolcott DL, Hines AH (1999a) Foraging and agonistic activity co-occur in free-ranging blue crabs (Callinectes sapidus): observation of animals by ultrasonic telemetry. J Exp Mar Biol Ecol 233:143-160

Clark ME, Wolcott TG, Wolcott DL, Hines AH (1999b) Intraspecific interference among foraging blue crabs Callinectes sapidus: interactive effects of predator density and prey patch distribution. Mar Ecol Prog Ser 178:69-78

$>$ Das T, Stickle WB (1993) Sensitivity of crabs Callinectes sapidus and $C$. similis and the gastropod Stramonita haemastoma to hypoxia and anoxia. Mar Ecol Prog Ser 98:263-274

> Das T, Stickle WB (1994) Detection and avoidance of hypoxic water by juvenile Callinectes sapidus and C. similis. Mar Biol 120:593-600

> De Goeij P, Luttikhuizen PC, van der Meer J, Piersma T (2001) Facilitation on an intertidal mudflat: the effect of siphon nipping by flatfish on burying depth of the bivalve Macoma balthica. Oecologia 126:500-506

Diaz RJ, Rosenberg R (1995) Marine benthic hypoxia: a review of its ecological effects and the behavioral responses of benthic macrofauna. Oceanogr Mar Biol Annu Rev 33:245-303

Diaz RJ, Neubauer RJ, Schaffner LC, Pihl L, Baden SP (1992) Continuous monitoring of dissolved oxygen in an estuary experiencing periodic hypoxia and the effect of hypoxia on macrobenthos and fish. Sci Total Environ (Suppl. 1992):1055-1068

Eby LA, Crowder LB (2004) Effects of hypoxic disturbances on an estuarine nekton assemblage across multiple scales. Estuaries 27:342-351

Eggleston DB, Lipcius RN, Hines AH (1992) Densitydependent predation by blue crabs upon infaunal clam species with contrasting distribution and abundance patterns. Mar Ecol Prog Ser 85:55-68

Eggleston DB, Bell GW, Amavisca AD (2005) Interactive effects of episodic hypoxia and cannibalism on juvenile blue crab mortality. J Exp Mar Biol Ecol 325:18-26

Grove M, Breitburg DL (2005) Growth and reproduction of gelatinous zooplankton exposed to low dissolved oxygen. Mar Ecol Prog Ser 301:185-198

Haas LW (1977) The effect of spring-neap tidal cycle on the vertical salinity structure of the James, York and Rappahannock Rivers, Virginia, USA. Estuar Coast Shelf Sci 5:485-496 
Henriksson R (1969) Influence of pollution on the bottom fauna of the sound (Øresund). Oikos 20:507-523

Hines AH, Comtois KL (1985) Vertical distribution of infauna in sediments of a subestuary of central Chesapeake Bay. Estuaries 8:296-304

Hines AH, Haddon AM, Wiechert LA (1990) Guild structure and foraging impact of blue crabs and epibenthic fish in a subestuary of Chesapeake Bay. Mar Ecol Prog Ser 67: 105-126

Holland AF, Mountford NK, Mihursky J (1977) Temporal variation in upper bay and mesohaline communities: I. The 9m mud habitat. Chesapeake Sci 18:370-378

Kemp WM, Boynton WR, Adolf JE, Boesch DF and others (2005) Eutrophication of Chesapeake Bay: historical trends and ecological interactions. Mar Ecol Prog Ser 303:1-29

Kuo AY, Neilson BJ (1987) Hypoxia and salinity in Virginia estuaries. Estuaries 10:277-283

Lenihan HS, Peterson CH, Byers JE, Grabowski JH, Thayer GW, Colby DR (2001) Cascading of habitat degradation: oyster reefs invaded by refugee fishes escaping stress. Ecol Appl 11:764-782

Lipcius RN, Eggleston DB, Heck KL, Seitz RD, Van Montfrans J (2007) Ecology of postlarvae and young juvenile blue crabs. In: Kennedy VS, Cronin LE (eds) The blue crab, Callinectes sapidus. Maryland Sea Grant, College Park, MD, p 535-564

Llansó RJ (1992) Effects of hypoxia on estuarine benthos: the lower Rappahannock River (Chesapeake Bay), a case study. Estuar Coast Shelf Sci 35:491-515

Long WC (2007) Hypoxia and Macoma balthica: ecological effects on a key benthic infaunal species. PhD dissertation, College of William and Mary, Virginia Institute of Marine Science, Gloucester Point, VA. www.vims.edu/library/ Theses/Long07.pdf

Long WC, Brylawski BJ, Seitz RD (2008) Behavioral effects of low dissolved oxygen on the bivalve Macoma balthica. J Exp Mar Biol Ecol 359:34-39

Menge BA, Olson AM (1990) Role of scale and environmental factors in regulation of community structure. Trends Ecol Evol 5:52-57

Menge BA, Sutherland JP (1987) Community regulation: variation in disturbance, competition, and predation in relation to environmental stress and recruitment. Am Nat 130:730-757

Nestlerode JA, Diaz RJ (1998) Effects of periodic environmental hypoxia on predation of a tethered polychaete, Glycera americana: implications for trophic dynamics. Mar Ecol

Editorial responsibility: Tom Minello,

Galveston, Texas, USA
Prog Ser 172:185-195

Officer CB, Biggs RB, Taft JL, Cronin LE, Tyler MA, Boynton WR (1984) Chesapeake Bay anoxia: origin, development, and significance. Science 223:22-27

> Orrock JL, Danielson BJ, Burns MJ, Levey DJ (2003) Spatial ecology of predator-prey interactions: corridors and patch shape influence seed predation. Ecology 84:2589-2599

Pihl L, Baden SP, Diaz RJ (1991) Effects of periodic hypoxia on distribution of demersal fish and crustaceans. Mar Biol 108:349-360

Pihl L, Baden SP, Diaz RJ, Schaffner LC (1992) Hypoxiainduced structural changes in the diet of bottom feeding fish and crustacea. Mar Biol 112:349-361

> Powers SP, Peterson CH, Christian RR, Sullivan E, Powers MJ, Bishop MJ, Buzzelli CP (2005) Effects of eutrophication on bottom habitat and prey resources of demersal fishes. Mar Ecol Prog Ser 302:233-243

> Rahel FJ, Nutzman JW (1994) Foraging in a lethal environment: fish predation in hypoxic waters of a stratified lake. Ecology 75:1246-1253

> Rosenberg R, Hellman B, Johansson B (1991) Hypoxic tolerance of marine benthic fauna. Mar Ecol Prog Ser 79: 127-131

Sagasti A, Schaffner LC, Duffy JE (2001) Effects of periodic hypozia on mortality, feeding and predation in an estuarine epifaunal community. J Exp Mar Biol Ecol 258: $257-283$

Seitz RD, Lipcius RN, Hines AH, Eggleston DB (2001) Density-dependent predation, habitat variation, and the persistence of marine bivalve prey. Ecology 82:2435-2451

> Seitz RD, Marshall LS Jr, Hines AH, Clark KL (2003) Effects of hypoxia on predator-prey dynamics of the blue crab Callinectes sapidus and the Baltic clam Macoma balthica in Chesapeake Bay. Mar Ecol Prog Ser 257:179-188

Seitz RD, Lipcius RN, Seebo MS (2005) Food availability and growth of the blue crab in seagrass and unvegetated nurseries of Chesapeake Bay. J Exp Mar Biol Ecol 319:57-68

Taylor DL, Eggleston DB (2000) Effects of hypoxia on an estuarine predator-prey interaction: foraging behavior and mutual interference in the blue crab Callinectes sapidus and the infaunal clam prey Mya arenaria. Mar Ecol Prog Ser 196: 221-237

Thomson RJ, Lake RS, Downes BJ (2002) The effect of hydrological disturbance on the impact of a benthic invertebrate predator. Ecology 83:628-642

Vermeij GJ (1987) Evolution and escalation: an ecological history of life. Princeton University Press, Princeton, NJ

Wu RSS (2002) Hypoxia: from molecular responses to ecosystem responses. Mar Pollut Bull 45:35-45

Submitted: September 19, 2007; Accepted: January 4, 2008 Proofs received from author(s): June 4, 2008 